\title{
DIABETIC NEPHROPATHY IN THE ELDERLY - CLINICAL PRACTICE
}

\author{
Klaudia Nadolnik', Damian Skrypnik², Katarzyna Skrypnik², Pawet Bogdański² \\ ${ }^{1}$ Faculty of Medicine I, Poznan University of Medical Sciences, Poznan, Poland \\ ${ }^{2}$ Department of Treatment of Obesity, Metabolic Disorders and Clinical Dietetics, Poznan University of \\ Medical Sciences, Szamarzewskiego 82/84, 60-569 Poznan, Poland \\ ${ }^{3}$ Institute of Human Nutrition and Dietetics, Poznan University of Life Science, Poznan, Poland
}

\begin{abstract}
Common health problems of the elderly in the near future will become even more common with aging of the population and longer average life expectancy. The elderly tend to have multiple disorders at one time, some of which may aggravate the course of others. One of the most common diseases, diabetes - "the epidemics of XXI century", treatment of which costs approximately $11 \%$ of world health care budget - is the leading reason of chronic kidney disease and end-stage renal disease. Diabetic nephropathy can be a complication of both diabetes mellitus type 1 and 2 . The most numerous group of patients with recently-made diagnosis are these above 60 years of age. Albuminuria, which, depending on its intensity, is one of the diagnostic criteria, can appear even in the process of aging itself. Overlapping of structural and functional changes that develop with age and those caused by diabetes is therefore a challenge, both diagnostic and clinical. There are certain methods of early diagnosis and prevention of progression of diabetic kidney disease. There is, however, no targeted treatment and existing therapies are generally based on glycemia and blood pressure control. Some patients in the advanced stage undergo dialyses just like in other kidney failure cases. The course of the disease is influenced by modifiable factors, such as protein and salt intake or cigarette smoking. In the light of the fact that this problem will concern an increasing number of patients, diagnostics and treatment can and should be introduced in the early stages of the disease. This all fits within the recently popular "healthy aging" ideology. Its popularization and implementation can bring measurable benefits of social and economic character.
\end{abstract}

Key words: diabetic nephropathies, healthy aging, diabetes mellitus, renal insufficiency, chronic kidney disease

\section{STRESZCZENIE}

Problemy zdrowotne powszechne wśród osób starszych wkrótce staną się jeszcze bardziej rozpowszechnione w związku ze starzeniem się populacji oraz szacowaną coraz dłuższą średnią życia. Osoby w podeszłym wieku charakteryzuje posiadanie wielu chorób równocześnie, przy czym niektóre z nich mogą pogarszać przebieg pozostałych. Jedna z najczęstszych - cukrzyca - „epidemia XXI wieku”, na której leczenie przeznacza się około 11\% światowego budżetu na ochronę zdrowia - jest wiodącą przyczyną przewlekłej choroby, a także schyłkowej niewydolności nerek. Cukrzycowa choroba nerek dotyka zarówno chorych na cukrzycę pierwszego, jak i drugiego typu. Najliczniejszą grupę pacjentów ze świeżą diagnozą stanowią ci powyżej 60. roku życia. Albuminuria, która, w zależności od nasilenia, jest jednym z kryteriów rozpoznania, pojawiać się może nawet w przebiegu samego procesu starzenia się organizmu. Nakładanie się pojawiających się wraz z wiekiem zmian struktury i funkcji nerek oraz zmian spowodowanych cukrzycą to zatem wyzwanie diagnostyczne oraz kliniczne. Istnieją określone metody wczesnego wykrywania oraz zapobiegania progresji cukrzycowej choroby nerek. Nie istnieje jednak celowane leczenie, a obecne terapie opierają się głównie na kontroli glikemii oraz ciśnienia tętniczego. Część pacjentów w zaawansowanym stadium jest poddawana dializom jak w innych przypadkach niewydolności nerek. Na przebieg choroby znaczny wpływ mają modyfikowalne czynniki, takie jak spożycie białka, soli, palenie tytoniu. W świetle faktu, że problem ten dotyczyć będzie coraz większej części społeczeństwa, diagnostyka i leczenie mogą i powinny być podejmowane już we wczesnych stadiach schorzenia. Wpisuje się to w ostatnio popularną ideologię „zdrowego starzenia się”, której popularyzacja i wprowadzanie w życie mogą przynieść wymierne korzyści społeczne, gospodarcze i ekonomiczne.

Słowa kluczowe: cukrzycowa choroba nerek, osoby starsze, cukrzyca, przewlekta choroba nerek, nefropatia cukrzycowa

Corresponding author: Damian Skrypnik, MD, PhD, Department of Treatment of Obesity, Metabolic Disorders and Clinical Dietetics, Poznan University of Medical Sciences / Katedra i Zakład Leczenia Otyłości, Zaburzeń Metabolicznych oraz Dietetyki Klinicznej, Uniwersytet Medyczny im. Karola Marcinkowskiego w Poznaniu, Szamarzewskiego 82/84, 60-569 Poznań, Poland, tel. +48 618549377 , fax. +4861 8478529, e-mail: dskrypnik@ump.edu.pl or damian.skrypnik@gmail.com

(C) Copyright by the National Institute of Public Health - National Institute of Hygiene 


\section{INTRODUCTION}

Each day the world is getting older - and so is its population. Average life expectancy at birth has increased by 20 years since 1950 and by 2050 is expected to extend by next 10 years. This means that number of people over 60 years of age should increase to almost 2 billion by 2050, which will be more than a fifth part of Earth's population. It was $10 \%$ in year 2010 [1]. It is also estimated that number of people over 85 years of age by 2050 should reach 20 million [2]. Ongoing XXI century is generally expected to bring exponential gain in average lifespan.

In Poland in 2008 the median of age of the whole population was 37 years, for 2060 it is expected to be the second highest in European Union - 58 years. In 2008 people of over 65 years old composed $13.5 \%$ of the population, in 2060 it is prognosed to grow to $36.2 \%$. For persons over 80 years of age these percentages are respectively $3.0 \%$ in 2008 and $13.1 \%$ in 2060 [3].

If people experience limitations caused by diseases, demands for social and health care will be greater [4]. The idea of "healthy aging" is popular and widely used, but it has not been specifically defined until WHO (World Health Organization's) report from 2015 defines it as "the process of developing and maintaining the functional ability that enables wellbeing in older age" [4]. Such well-being, however, is not often achieved and the main reason for this are chronic diseases. Age increases the risk of many health disorders. So-called multimorbidity affects more than half of the elderly population [5]. Among the most common health problems of the elderly cardiovascular, respiratory and oncological diseases also DM (diabetes mellitus) should be mentioned [4]. Impaired glucose tolerance is related to aging [6] and diabetic patients experience geriatric syndromes more often [7]. These include falls and fractures, depression, polypharmacy, vision and hearing impairment and urinary incontinence. Such patients also were found to have a weaker functional status and greater muscle loss [8].

Diabetes was the first non-infectious disease to be called by the United Nations "the epidemic of XXI century". Every 10 seconds in the world a new diagnosis of DM is made. In last three decades in the United States of America its incidence has grown by $200 \%$ [9]. Almost 415 million people around the world have diabetes mellitus. It is estimated that every 6 seconds a patient dies of its complications. IDF (International Diabetes Federation) reported 5 million deaths worldwide from diabetes in 2015, while 1,5 million deaths was caused by HIV (Human Immunodeficiency Virus), 1,5 million by tuberculosis and 0,6 million by malaria. It is estimated that in year 2040 there will be over 642 million people suffering from diabetes [10], including 71,1 million in Europe, which will be equal to over $10 \%$ of its population for that time. In year 2013 in Poland approximately 2,7 million people suffered from diabetes, 550 thousands of which were not even conscious of the disease. Here a new diagnosis is made every 20 minutes, which in a year perspective equals to almost 30 thousands new patients. It is not only a social or a medical problem - the economical demand for treating DM and its complications is enormous too, estimated to be around $11 \%$ of world health care budget. In 2014 global health expenditures for this reached 1197 billion dollars [11].

The main diabetic mortality and disability causes include micro- and macroangiopathy-associated disorders: cardiovascular events, retinopathy (it is a major cause of blindness in the United States [12]), neuropathy, vasculopathy (the leading cause of nontraumatic lower limb amputations in the United States [13]) and finally nephropathy. Diabetes is a risk factor for CKD (chronic kidney disease) additionally because of the coexisting hypertension and quicker atherosclerosis $[14,15]$. Kidney disease development risk is much greater in diabetics that in non-diabetics. It is also amplified in older individuals $[16,17]$. In the elderly a range of factors aggravate diabetic kidney disorder- these are: aging itself, diabetes duration, previous kidney disorders (e.g. ischemic nephropathy), hypertension, atherosclerosis, obesity, heart failure, smoking cigarettes, geriatric hypodipsia $[14,18]$. The accumulation of these partially explains the growing frequency of diabetic nephropathy in the elderly [14]. Correct blood pressure control in the elderly with diabetic kidney disease and GFR (glomerular filtration rate) $>60 \mathrm{ml} / \mathrm{min} / 1.73 \mathrm{~m}^{2}$ significantly reduces the need of specialist nephrological treatment [19].

In Poland in 2011 approximately 36\% of cases of arterial hypertension were treated improperly, 30\% - still undiagnosed, 9\% diagnosed but not treated and finally only $26 \%$ treated adequately [20]. Basing on NATPOL 2002-2011 estimation, it is prognosed that in $202046 \%$ of hypertension cases will be properly managed, $28 \%$ improperly, $5 \%$ untreated and $20 \%$ will remain undiagnosed [21]. Not even half of patients with hypertension treated properly implicates that in the group of patients with diabetic CKD course of this disease will be still exacerbated.

The aim of the paper is to present the clinical problems of diabetic nephropathy in the light of aging population.

\section{Diabetic nephropathy classification and diagnosis}

Diabetes has been thought of together with kidneys for a very long time. Aretaeus the Cappadocian, an ancient Greek physician, named a characteristic assemblage of symptoms "diabētēs" - meaning a siphon, referring to the excessive urination patients 
presented with [22]. Galen regarded it as a kidney disease and such belief had lasted for over one and a half thousand years [23]. In XIX century it was understood that diabetes mellitus is a disease of pancreas and nephropathy is its complication [24, 25].

Diabetic nephropathy is characterized by persistent albuminuria (more than $0.3 \mathrm{~g} /$ day) in a diabetic type either 1 or 2; what may also be observed are progressive decline of GFR and elevated arterial blood pressure.

Newest classification of diabetic nephropathy [26] divides it into five categories:

1) pre-nephropathy - normoalbuminuria $(<30 \mathrm{mg} / \mathrm{g}$ creatinine) and GFR $30 \mathrm{ml} / \mathrm{min} / 1.73 \mathrm{~m}^{2}$ or over

2) incipient nephropathy - microalbuminuria (30-299 $\mathrm{mg} / \mathrm{g}$ creatinine) and GFR $30 \mathrm{ml} / \mathrm{min} / 1.73 \mathrm{~m}^{2}$ or over

3) overt nephropathy - macroalbuminuria $(300 \mathrm{mg} / \mathrm{g}$ creatinine or over) or persistent proteinuria $(0.5 \mathrm{~g}$ or over per gram of creatinine) and GFR $30 \mathrm{ml} /$ $\min / 1.73 \mathrm{~m}^{2}$ or over

4) kidney failure - any with GFR under $30 \mathrm{ml} /$ $\min / 1.73 \mathrm{~m}^{2}$

5) dialysis therapy - any status with ongoing dialyses
All patients with GFR of less than $30 \mathrm{ml} / \mathrm{min} / 1.73$ $\mathrm{m}^{2}$ are classified as having kidney failure, regardless of their urinary albumin or protein excretion, but in those with normoalbuminuria and microalbuminuria, a differential diagnosis is required between diabetic and any other possible non-diabetic nephropathy [26].

To estimate glomerular filtration rate, various formulas may be used, among them eGFR (estimated glomerular filtration rate) based on the abbreviated MDRD (Modification of Diet in Renal Disease) being previously the most commonly used worldwide [27]. The newer CKD-EPI (Chronic Kidney Disease Epidemiology Collaboration) equation was proved to be as accurate as MDRD in those with eGFR $<60 \mathrm{ml} / \mathrm{min} / 1.73 \mathrm{~m}^{2}$ and considerably more adequate in those with eGFR $>60 \mathrm{ml} /$ $\mathrm{min} / 1.73 \mathrm{~m}^{2}[28,29]$; however, among the oldest it might actually increase CKD occurrence estimates [30]. In the elderly it is crucial to use equations which take patient's age into consideration [19]. Two meta-analyses found cystatin $\mathrm{C}$ better than creatinine in assessing kidney function [31,32]; in another cystatin C was more sensitive, but less specific [33]. This method is more expensive and is recommended mainly for confirmation of CKD in the absence of other markers of kidney damage [34].

MDRD for serum creatinine concentration (Scr) in $\mathbf{~ m g / d l : ~}$

for women: eGFR $\left[\mathrm{ml} / \mathrm{min} / 1.73 \mathrm{~m}^{2}\right]=186 \times[\mathrm{Scr}]^{-1.154} \times(\text { age })^{-0.203} \times 0.742$

for men: eGFR $\left[\mathrm{ml} / \mathrm{min} / 1.73 \mathrm{~m}^{2}\right]=186 \times[\mathrm{Scr}]^{-1.154} \times(\text { age })^{-0.203}$

MDRD for serum creatinine concentration (Scr) in $\boldsymbol{\mu m o l} / \mathbf{l}$ :

for women: eGFR $\left[\mathrm{ml} / \mathrm{min} / 1.73 \mathrm{~m}^{2}\right]=186 \mathrm{x}[\mathrm{Scr} / 88.4]^{-1.154} \mathrm{x}(\text { age })^{-0.203} \times 0.742$

for men: eGFR $\left[\mathrm{ml} / \mathrm{min} / 1.73 \mathrm{~m}^{2}\right]=186 \times[\mathrm{Scr} / 88.4]^{-1.154} \times(\text { age })^{-0.203}$

or

\section{CKD-EPI}

$\mathrm{GFR}=141 \times \min (\mathrm{Scr} / \mathrm{k}, 1)^{\mathrm{a}} \times \max (\mathrm{Scr} / \mathrm{k}, 1)^{-1.209} \times(0.993)^{\mathrm{age}} \times 1.018$ [for women]

$\mathrm{Scr}$ - serum creatinine concentration $[\mathrm{mg} / \mathrm{dl}], \mathrm{k}-0.7$ for women and 0.9 for men, $\mathrm{a}--0.329$ for women and -0.411 for men

Figure 1. Estimating GFR taking patient's age into consideration [27, 29].

Table 1. Assessment of albuminuria [19]

\begin{tabular}{|l|c|c|c|}
\hline \multicolumn{1}{|c|}{ Category } & $\begin{array}{r}\text { AER } \\
{[\mathrm{mg} / \mathrm{day}]}\end{array}$ & $\begin{array}{r}\text { ACR } \\
\text { (random urine test) } \\
{[\mathrm{mg} / \mathrm{day} \text { or } \mathrm{mg} / \mathrm{g} \text { creatinine }]}\end{array}$ & $\begin{array}{c}\text { Albumin excretion } \\
{[\mu \mathrm{m} / \mathrm{min}] \text { in urine collection }}\end{array}$ \\
\hline $\begin{array}{l}\text { Normoalbuminuria or insignificantly } \\
\text { increased albuminuria }\end{array}$ & $<30$ & $<30$ & $\geq 20$ \\
\hline Moderate albuminuria & $30-300$ & $30-300$ & $\geq 20$ but $<200$ \\
\hline Evident proteinuria & $>300$ & $>300$ & $\geq 200$ \\
\hline
\end{tabular}

AER- albumin excretion rate, ACR- albumin/creatinine ratio 
Approximately one in three diabetic patient is in great risk of developing kidney problems [35]. In such patients, in order to detect or to determine the severity of kidney disease, blood creatinine level, albuminuria and estimated glomerular filtration rate should be assessed [19]. The last two are independent predictors of cardiovascular risk [36, 37]. In diabetes type 2 albuminuria screening should be done immediately after diagnosis, in type 1 it should be undertaken from fifth year on after diagnosis - in both types then performed annually. Before this, a general urinalysis ought to be performed to rule out evident proteinuria or infection. If there was proteinuria in this test, there is no need for screening for albuminuria. ACR (albumin/creatinine ratio) based on morning urine collection or AER (albumin excretion rate) based on albumin concentration in 24-hour or single morning collection should be assessed. Albuminuria from 24hour collection can be treated equally to albuminuria expressed in mg per $1 \mathrm{~g}$ of creatinine. If AER comes out as positive, it should be repeated twice in the following 3 months. Two positive results out of three imply albuminuria. It should be noted that albuminuria may appear after physical exertion, in infections, hyperglycemia, heart failure or during a high blood pressure episode [19, 38, 39].

\section{Morphological changes in diabetic nephropathy and in aging kidney}

The earliest pathologies in the process of chronic kidney disease in diabetes mellitus are thickening of GBM (glomerular basement membrane) and mesangial expansion caused by hyperglycemia and - in consequence - accretion of extracellular matrix. What thickens GBM are proteins deposited along it, like collagen IV. GBM also loses negatively charged polysaccharides like heparan sulfate - this deprives the membrane of its original charge and allows positively charged albumins to get through. The broader peripheral GBM, the greater the mesangium or the more matrix, the more severe is patient's state [35]. Also the basement membrane of renal tubules gets 2-3 times thicker - this, however, does not occur in patients treated with ACEI (angiotensin converting enzyme inhibitors) [40]. Glomeruli vessels are narrowed by hyalinization, but afferent renal arteries remain dilated, which causes intraglomerular hypertension. Interstitial fibrosis adds to progressive decline in glomerular filtration rate. Proteinuria is finally caused by fusion of podocytes' pedicels, depletion of the epithelial cells and their broadening [41]. Pathognomonic KimmelstielWilson lesions (nodular glomerulosclerosis) can be found only in $20 \%$ of patients [42].

In a healthy individual it is considered normal to develop kidney changes caused by aging [43]
Nephrons lose their function, which is partially reflected in decreasing their mass. The other glomeruli compensate this loss by hypertrophy caused by functional overload [44, 45]. Vessels and glomeruli undergo fibrosis, especially in the core of the kidney. In its medulla this process creates channels between afferent and efferent arteries - apparently, this is a method of maintaining medullary flow [46, 47]. Increasing number of renal tubules undergo atrophy at the expense of functional structures [48]. Renal blood flow decreases, but vascular resistance and filtration both rise. It is estimated that since 40th year of age renal blood flow decreases by $10 \%$ each decade of life [49]. GFR also decreases - approximately $1 \mathrm{ml} / 1,73 \mathrm{~m}^{2}$ per year. The GFR decline increases significantly after 65 th year of age [50]. In the elderly less aldosterone is secreted and the renal tubules are less sensitive to it $[47,51]$. At the same time renin-angiotensinaldosterone tissue systems are more active, which makes vessels, heart and central nervous system more prone to its action [14].

The similarities of physiological aging of the kidneys and pathologies occuring in CKD might make differentiating between them difficult. The largest age group with newly diagnosed diabetic nephropathy are patients over 60 years old. The common features of both aging and diabetic kidney disease are decrease in GFR and sodium and water reabsorption ability in the renal tubules. It often manifests as polyuria and nocturia [51, 52]. Aging (in opposition to CKD) does not impair the proximal tubule function, magnesium and phosphate excretion nor interfere with erythropoietin secretion $[53,54]$. Both aging and CKD lead to decreased activity of 1-alpha-hydroxylase and so - synthesis of active form of vitamin D. A compensating, secondary hyperparathyroidism therefore occurs, which is a way to maintain calcium levels in blood. This process is much less evident in only aging than in CKD itself [51, $55,56]$. Albuminuria gradually gets higher throughout life. It might also be a sign of destruction of the leaking membrane in early stages of CKD, but in this case albuminuria is getting severe fast and transforms into evident proteinuria [57, 58]. Recently number of patients with end-stage renal disease connected to diabetes has grown by over a dozen percent, outrunning all other reasons: chronic glomerulonephritis, hypertensive nephropathy and polycystic kidney disease [59].

\section{Treatment}

There are several goals of general diabetic nephropathy prevention: optimal blood glucose control (HbA1C $<7 \%$ ), avoiding non steroid antiinflammatory drugs, aminoglycosides and other nephrotoxic medications [19], with critical determinant being blood pressure control $(<120 / 70 \mathrm{mmHg})$ [34]. 
Pharmacotherapy interventions in the therapy of diabetic nephropathy focus on glycaemia control and hypertension treatment. Hyperglycemia has been proved to be the major determinant of the progression of CKD in diabetic patients with either type 1 or 2 diabetes mellitus. Intensive therapy may partially reverse glomerular hypertrophy, hyperfiltration and delay the development of albuminuria. In case of albuminuria ACEI or ARB (angiotensin II receptor blockers) use should be initiated to slow down nephropathy progression. In the elderly who are more prone to side effects of these drugs, therapy should be started with low doses (approximately 25\% of the target dose) and adjusted according to GFR and drug tolerance. As in any other disease, these two classes should not be prescribed together, as it puts the patient in a much greater risk of side effects (including kidney failure). Thiazide diuretics can be beneficial for patients with GFR $>30 \mathrm{ml} / \mathrm{min} / 1.73 \mathrm{~m}^{2}$; below this value loop diuretics should be prescribed. This group of drugs, however, puts the patient in the risk of dyselectrolytemia and dehydration, in which also decreased glomerular filtration and geriatric hypodipsia play a great role. These side effects are a frequent hospitalization cause and they require immediate medical interventions, therefore any elderly diabetic patient who presents with symptoms such as mouth dryness, weakness, sudden-onset thirst, drowsiness, muscle cramps, hypotension, oliguria, tachycardia, nausea, vomiting should be clinically evaluated for these possible reversible causes. Patients who use ACEI/ARB and/or diuretics should have creatinine and potassium levels monitored. Yearly albuminuria evaluation has not proven effective as long as the treatment is optimal. If GFR is below 60 $\mathrm{ml} / \mathrm{min} / 1.73 \mathrm{~m}^{2}$ or if there are obstacles in effective hypertension treatment, a nephrological consultation should be considered. Nephrological consultation is obligatory if GFR is below $30 \mathrm{ml} / \mathrm{min} / 1.73 \mathrm{~m}^{2}$ [19]. Nowadays it is assumed that a pre-emptive kidney transplantation - done before dialyses - gives patients in end-stage renal disease greater chance of long-term survival [60-63].

Metformin can be used without extraordinary limitations in patients with GFR $>60 \mathrm{ml} / \mathrm{min} / 1.73 \mathrm{~m}^{2}$ [64]. In this case kidney function should be evaluated once a year. If GFR is $45-59 \mathrm{ml} / \mathrm{min} / 1.73 \mathrm{~m}^{2}$, such evaluation should be done once in 3-6 months. In GFR range $30-44 \mathrm{ml} / \mathrm{min} / 1.73 \mathrm{~m}^{2}$ metformin dose reduction to $50 \%$ of an already used metformin should be considered and kidney function should be evaluated every 3 months. Newly diagnosed patients with GFR $20-44 \mathrm{ml} / \mathrm{min} / 1.73 \mathrm{~m}^{2}$ should not be prescribed metformin $[19,65]$.

\section{Diet in diabetic nephropathy}

In diet of diabetic patients carbohydrates should not exceed $45 \%$ of daily calorie intake. However, if they come from fibre-rich and low GI (glycemic index) food products, this percentage can reach $60 \%$. Albuminuria risk is greater in individuals who consume large amounts of proteins in their everyday diet. It is particularly high in patients, who intake $20 \%$ or more of their daily energy from proteins. This risk can be even greater in those who suffer from arterial hypertension. It has been proven that daily protein intake reduction to $0,6-0,7 \mathrm{~g}$ /day leads to decrease of the CKD progression by $44 \%$ [66].

In all patients with diabetic nephropathy daily protein consumption should be reduced to $0.8-1 \mathrm{~g} / \mathrm{kg}$ body mass $[67,68]$. If GFR is below $60 \mathrm{ml} / \mathrm{min} / 1.73$ $\mathrm{m}^{2}$ and in case of evident proteinuria this should be less than $0.8 \mathrm{~g} / \mathrm{kg}$ body mass, making it about $10 \%$ of calorie intake [19].

Patients without albuminuria should avoid protein-rich foods, especially those from animals, but proteins can amount up to $20 \%$ of their diet. In this group of patients it is recommended to limit proteinrich foods to one meal per day. The preferred type of protein is plant-derived one [19]. Salt intake reduction is a well-proven hypotensive intervention similar in cardiovascular and renal benefits to single-drug antihypertensive therapy, therefore diabetic patients should consider reducing daily salt intake to 5-6 g or even less to slow down the progression of kidney disease [69]. Obesity, metabolic syndrome and high alcohol consumption may play an important role in the pathogenesis of diabetic nephropathy [70]. Thus, calorie intake reduction and decrease in alcohol intake can benefit patients highly. Many researchers have proven that diet antioxidants have a positive impact on renal function in diabetic nephropathy [71, 72], so does physical exertion [73]. Smoking is an independent risk factor of CKD development and progression in DM type 2 patients [74]. Smoking cessation significantly reduces the risk of diabetic nephropathy [71].

\section{CONCLUSIONS}

10 -year mortality in DM type 1 patients is 1980 s is estimated to have been $50-77 \%$, while in the first decade of XXI century it amounted to $18 \%$. Main death reasons were hypertension and uremia. DM type 2 patients with CKD and arterial hypertension have a year survivability of approximately $75 \%$ and 5 -year survivability of three times less. These with CKD and treated with dialyses have a year survivability of 60$70 \%$ and 5 -year survivability of $15-20 \%$ [75]. Thus, an evident need for effective treatment of diabetic nephropathy emerges. 
As the society is getting older, diabetic nephropathy will be increasingly prevalent, therefore general practitioners should be able to detect it in the earliest stages possible. Differentiating normal course of aging and nephropathy in a diabetic patient should be widely performed. Actually, there might be a need for adjusting current formulas for estimating glomerular filtration rate in patients that are both older and diabetic. Renal degeneration caused by aging is inevitable and a full recovery from an already developed kidney disease is not possible, but adequate treatment and actions may significantly slow down its progression. Early detection and medical care in the elderly patients with diabetic nephropathy is one of the key elements of "healthy aging".

\section{Conflict of interest}

The authors declare no conflict of interest.

\section{REFERENCES}

1. United Nations: Political Declaration and Madrid International Plan of Action on Ageing 2002. Available at: http://www.un.org/en/events/pastevents/pdfs/ Madrid_plan.pdf (Accessed 14.05.2018)

2. European Commission: The social situation in the European Union 2005-2006. Available http:// ec.europa.eu/employment_social/social_situation/docs/ ssr2005_2006_en.pdf (Accessed 14.05.2018)

3. Ortman J.M.: U.S. Population Trends: 2000 to 2060: Webinar for the Minority Business Development Agency. US Department of Commerce 2014. Available https://www.mbda.gov/sites/mbda.gov/files/migrated/ files-attachments/Demographics_Webinar.pdf (Accessed 14.05.2018)

4. World Health Organization: World Report on Ageing and Health. WHO Press 2015. Available http://apps.who.int/ iris/bitstream/handle/10665/186463/9789240694811 eng.pdf;jsessionid=787149ABB135949E56370D5042 43E73E? sequence $=1$ (Accessed 14.05.2018)

5. Marengoni A., Angleman S., Melis R., Mangialasche F., Karp A., Garmen A. et al.: Aging with multimorbidity: a systematic review of the literature. Ageing Res Rev 2011;10(4):430-439 doi:10.1016/j.arr.2011.03.003.

6. Chang A.M., Halter J.B.: Aging and insulin secretion. Am J Physiol Endocrinol Metab 2003;284(1):E7-12 doi:10.1152/ajpendo.00366.2002.

7. Laiteerapong, N., Karter, A. J., Liu, J. Y., Moffet, H. H., Sudore, R., Schillinger, D., John P.M., Huang, E. $S$.: Correlates of Quality of Life in Older Adults With Diabetes: The Diabetes \& Aging Study. Diabetes Care 2011;34(8):1749-1753 doi:10.2337/dc10-2424.

8. Kalyani R.R., Corriere M., Ferrucci L.: Agerelated and disease-related muscle loss: the effect of diabetes, obesity, and other diseases. Lancet Diabetes Endocrinol 2014;2(10):819-829 doi:10.1016/S22138587(14)70034-8.

9. Ogurtsova K., da Rocha Fernandes J., Huang Y., Linnenkamp U., Guariguata L., Cho N.H., Cavan D.,
Shaw J.E., Makaroff L.E.: IDF Diabetes Atlas: Global estimates for the prevalence of diabetes for 2015 and 2040. Diabetes Res Clin 2017;128;40-50 doi:10.1016/j. diabres.2017.03.024.

10. United Nations General Assembly: Political declaration of the High-level Meeting of the General Assembly on the Prevention and Control of Non-communicable Diseases. 2011 Available http://www.who.int/nmh/ events/un_ncd_summit2011/political_declaration_ en.pdf (Accessed 14.05.2018)

11. da Rocha Fernandes J., Ogurtsova K., Linnenkamp U., Guariguata L., Seuring T., Zhang P., Cavan D., Makaroff L.E.: IDF Diabetes Atlas estimates of 2014 global health expenditures on diabetes. Diabetes Res Clin Pract 2016;117: 48-54 doi:10.1016/j.diabres.2016.04.016.

12. Cheung N., Mitchell P., Wong T.Y.: Diabetic retinopathy. Lancet 2010;376(9735):124-136 doi:10.1016/S01406736(09)62124-3.

13. Centers for Disease Control and Prevention (CDC) National Diabetes Fact Sheet: National Estimates and General Information on Diabetes in the United States. Atlanta, GA: U.S. Department of Health and Human Services, CDC 1999. Available https://www. cdc.gov/diabetes/pubs/pdf/ndfs_2011.pdf (Accessed 14.05.2018)

14. ChudekJ., Wikarek T., Więcek A.: Epidemia przewlekłej choroby nerek w populacji osób w podeszłym wieku jako nakładanie się procesu fizjologicznego starzenia i nabytych uszkodzeń nerek [Epidemic of chronic kidney disease of the aging population - physiological aging and acquired kidney injuries]. Forum Nefrologiczne 2013;6(1):1-8 (in Polish).

15. Mazzone T., Chait A., Plutzky J.: Addressing cardiovascular disease risk in diabetes: insights from mechanistic studies. Lancet 2008;371(9626):18001809 doi:10.1016/S0140-6736(08)60768-0.

16. Kazancioğlu R.: Risk factors for chronic kidney disease: an update. Kidney Int Suppl 2013;3(4):368371 doi:10.1038/kisup.2013.79.

17. Fox C.S., Larson M.G., Leip E.P., Culleton B., Wilson P.W.F., Levy D.: Predictors of NewOnset Kidney Disease in a Community-Based Population. JAMA 2004;291(7):844-850 doi:10.1001/ jama.291.7.844.

18. Skrypnik K, Suliburska J, Skrypnik D, Pilarski E, Regula J, Bogdański P.: The genetic basis of obesity complications. Acta Sci Pol Technol Aliment 2017;16(1):83-91 doi: 10.17306/J.AFS.2017.0442.

19. Polskie Towarzystwo Diabetologiczne: Zalecenia kliniczne dotyczące postępowania u chorych na cukrzycę 2017. Stanowisko Polskiego Towarzystwa Diabetologicznego [2017]. Guidelines on the management of diabetic patients. A position of Diabetes Poland]. Via Medica 2017;3(A).

20. Prevalence and control of cardiovascular risk factors in Poland. The NATPOL 2011 Survey.

21. Polskie Towarzystwo Nadciśnienia Tętniczego: Estymacja NATPOL 2020: opracowanie PTNT na bazie trendu $2002-2011$ [NATPOL 2020 estimation: PTNT report basing on $2002-2011$ trend] In: Narkiewicz K.: Nadciśnienie tętnicze 2013: Polska na tle świata 
[Arterial hypertension 2013: Polish compared to the rest of the world] Available www.who.un.org.pl/common/ files_download.php?fid=27 (Accessed 15.05.2018)

22. Henschen F.: On the term Diabetes in the works of Aretaeus and Galen. Med Hist 1969;13:190-192.

23. Feudtner C.: Bittersweet: Diabetes, Insulin and Transformation of Illness. Chapel Hill, University of North Caroline Press, 2003.

24. Lakhtakia R.: The History of Diabetes Mellitus. Sultan Qaboos Univ Med J 2013;13(3):368-370.

25. Ahmed A.M.: History of diabetes mellitus. Saudi Med J 2002;23(4):373-378.

26. Haneda, M., Utsunomiya, K., Koya, D., Babazono, T., Moriya, T., Makino, H., Kimura K., Suzuki Y., Wada T., Ogawa S., Inaba M., Kanno Y., Shigematsu T., Masakane I., Tsuchiya K., Honda K., Ichikawa $K$., Shide $K$. and Joint Committee on Diabetic Nephropathy: A new Classification of Diabetic Nephropathy 2014: a report from Joint Committee on Diabetic Nephropathy. J Diabetes Investig 2015;6(2):242-246 doi:10.1111/jdi.12319.

27. Florkowski C.M., Chew-Harris J.S.: Methods of Estimating GFR - Different Equations Including CKDEPI. Clin Biochem Rev 2011;32(2):75-79.

28. Kilbride H.S., Stevens P.E., Eaglestone G., Knight S., Carter J.L., Delaney M.P., Farmer C.K., Irving J., O'Riordan S.E., Dalton R.N., Lamb E.J.: Accuracy of the MDRD (Modification of Diet in Renal Disease) Study and CKD-EPI (CKD Epidemiology Collaboration) Equations for Estimation of GFR in the Elderly. Am J Kidney Dis 2013;61(1):57-66 doi: 10.1053/j.ajkd.2012.06.016.

29. Levey A.S., Stevens L.A., Schmid C.H., Zhang Y., Castro A.F., Feldman H.I., Kusek J.W., Eggers P., Van Lente F., Greene T., Coresh J.: A New Equation to Estimate Glomerular Filtration Rate. Ann Intern Med 2009;150:604-612 doi:10.7326/0003-4819-150-9200905050-00006.

30. Carter J.L., Stevens P.E., Irving J.E., Lamb E.J.: Estimating glomerular filtration rate: comparison of the CKD-EPI and MDRD equations in a large UK cohort with particular emphasis on the effect of age. QJM 2011;104(10):839-847 doi:10.1093/qjmed/hcr077.

31. Dharnidharka V.R., Kwon C., Stevens G.: Serum cystatin $\mathrm{C}$ is superior to serum creatinine as a marker of kidney function: a meta-analysis. Am J Kidney Dis 2002;40(2):221-226 doi:10.1053/ajkd.2002.34487.

32. Roos J.F., Doust J., Tett S.E., Kirkpatrick C.M.: Diagnostic accuracy of cystatin $\mathrm{C}$ compared to serum creatinine for the estimation of renal dysfunction in adults and children - a meta-analysis. Clin Biochem 2007;40(5-6):383-391.

33. Pan P., Binjie H., Min L., Lipei F., Yanli N., Junwen Z., Xianghua S.: A Meta-analysis on diagnostic value of serum cystatin $\mathrm{C}$ and creatinine for the evaluation of glomerular filtration function in renal transplant patients. Afr Health Sci 2014;14(4):1025-1035 doi:10.4314/ahs.v14i4.34.

34. Stevens P.E. Levin A., Kidney Disease: Improving Global Outcomes Chronic Kidney Disease Guideline Development Work Group Members: Evaluation and
Management of Chronic Kidney Disease: Synopsis of the Kidney Disease: Improving Global Outcomes 2012 Clinical Practice Guideline. Ann Intern Med 2013;158(11):825-830 doi:10.7326/0003-4819-158-11201306040-00007.

35. Parving H.H., Mauer M., Ritz E.: Diabetic nephropathy. In: Brenner B.M., Rector F.C. Brenner and Rector's The Kidney. Philadelphia, Saunders, 2004.

36. Mathisen U.D., Melsom T., Ingebretsen O.C., Jenssen T., Njølstad I., Solbu M.D., Toft I., Eriksen B.O.: Estimated GFR Associates with Cardiovascular Risk Factors Independently of Measured GFR. J Am Soc Nephrol 2011;22(5):927-937 doi: 10.1681/ASN.2010050479.

37. Pontremoli R.: Microalbuminuria in essential hypertension - its relation to cardiovascular risk factors. Nephrol Dial Transplant 1996;11:2113-2134 doi:10.1093/oxfordjournals.ndt.a027119.

38. Renko M., Tapanainen P., Tossavainen P., Pokka T., Uhari M.: Meta-Analysis of the Significance of Asymptomatic Bacteriuria in Diabetes. Diabetes Care 2011;34(1):230-235 doi:10.2337/dc10-0421.

39. Koh K.H., Dayanath B., Doery J.C., Polkinghorne K.R., Teede H., Kerr P.G.: Effect of exercise on albuminuria in people with diabetes. Nephrology (Carlton) 2011;16(8):704-709 doi:10.1111/j.14401797.2011.01508.x.

40. 40.Cordonnier D.J., Pinel N., Barro C., Maynard M., Zaoui P., Halimi S., Hurault de Ligny B., Reznic Y., Simon D., Bilous R. W.: Expansion of cortical intersitium is limited by converting enzyme inhibition in type 2 diabetic patients with glomerulosclerosis. J Am Soc Nephrol 1999;10(6):1253-63.

41. Arakawa M.: A scanning electron microscopy of the glomerulus of normal and nephrotic rats. Lab Invest 1970;23:489-496.

42. Friedman E.A.: Renal syndromes in diabetes. Endocrinol Metab Clin North Am 1996;25(2):293-324.

43. Denic A., Glassock R.J., Rule A.D.: Structural and functional changes with the aging kidney. Adv Chronic Kidney Dis 2016;23(1):19-28 doi:10.1053/j. ackd.2015.08.004.

44. Goyal V.K.: Changes with age in the human kidney. Exp Gerontol 1982;17:321-331.

45. McLachlan M.S.: The ageing kidney. Lancet 1978;15:143-146.

46. Takazakura E., Sawabu N., Handa A., Takada A., Shinoda A., Takeuchi J.: Intrarenal vascular changes with age and disease. Kidney Int 1972; 2(4): 224-230.

47. Ljungqvist A., Lagergren C.: Normal intrarenal arterial pattern in adult and ageing human kidney. A microangiographical and histological study. J Anat 1962;96:285-300.

48. Kasiske B.L.: Relationship between vascular disease and age associated changes in the human kidney. Kidney Int 1987;31:1153-1159.

49. Hollenberg N.K., Adams D.F., Solomon H.S. Rashid A., Abrams H.L., Merrill J.P.: Senescence and the renal vasculature in normal man. Circ Res 1974;34:309-316.

50. Khan I.H., Catto G.R., Edward N., Macleod A.M.: Acute renal failure: factors influencing nephrology referral and outcome. QJM 1997;90:781-785. 
51. Plante G.E.: Impact of aging on the body's vascular system. Metabolism 2003;52(2):31-35.

52. Murata K., Horiuchi Y.: Age-dependent distribution of acidic glycosaminoglycans in human kidney tissue. Nephron 1978;20:111-118.

53. Cullen-McEwen L.A., Kett M.M., Dowling J., Anderson W.P., Bertram J.F.: Nephron number, renal function, and arterial pressure in aged GDNF heterozygous mice. Hypertension 2003;41:335-340.

54. Thomson S.C., Vallon V., Blantz R.C.: Kidney function in early diabetes: the tubular hypothesis of glomerular filtration. Am J Physiol Renal Physiol 2004;286:F8-F15.

55. Lindeman R.D., Tobin J.D., Shock N.W.: Association between blood pressure and the rate of decline in renal function with age. Kidney Int 1984;26:861-868.

56. Fliser D., FranekE., Joest M., BlockS., Mutschler E., Ritz $E$.: Renal function in the elderly: impact of hypertension and cardiac function. Kidney Int 1997;51:1196-1204.

57. McMurdo M.E.: A healthy old age: realistic or futile goal? Br Med J 2000;321:1149-1151.

58. James M.A., Fotherby M.D., Potter J.F.: Screening tests for microalbuminuria in non-diabetic elderly subjects and their relation to blood pressure. Clin Sci 1995;88:185-190.

59. United States Renal Data System: 2012 Atlas of CKD \& ESRD. Available http://www.usrds.org/atlas.aspx (Accessed 14.05.2018)

60. Meier-Kriesche H.U., Port F.K., Ojo A.O., Rudich S.M., Hanson J.A., Cibrik D.M., Leichtman A.B., Kaplan $B$.: Effect of waiting time on renal transplant outcome. Kidney Int 2000;58(3):1311-1317 doi:10.1046/j.15231755.2000.00287.x.

61. Mange K.C., Joffe M.M., Feldman H.I.: Effect of the use or nonuse of long-term dialysis on the subsequent survival of renal transplants from living donors. $\mathrm{N}$ Engl J Med 2001;344(10):726-731 doi:10.1056/ NEJM200103083441004.

62. Kasiske B.L., Snyder J.J., Matas A.J., Ellison M.D., Gill J.S., Kausz A.T.: Preemptive kidney transplantation: the advantage and the advantaged. J Am Soc Nephrol 2002;13(5):1358-1364.

63. Gill J.S., Tonelli M., Johnson N., Pereira B.J.: Why do preemptive kidney transplant recipients have an allograft survival advantage? Transplantation 2004;78(6):873-879.

64. European Medicines Agency: Summary Information on a Referral Opinion Following an Arbitration Pursuant to Article 11 of Council Directive 75/319/ EEC as Amended, for Glucophage/Glucophage Forte/ Risidon/Dianben. Available http://www.ema.europa.eu/ docs/en_GB/document_library/Referrals_document/ Glucophage_30/WC500011044.pdf(Accessed 14.05.2018)

65. US Food and Drug Administration: FDA Drug Safety Communication: FDA Revises Warnings Regarding Use of the Diabetes Medicine Metformin in Certain Patients with Reduced Kidney Function 2016. Available at: http://www.fda.gov/downloads/Drugs/DrugSafety/ UCM494140.pdf (Accessed 14.05.2018).
66. Pedrini M.T., Levey A.S., Lau J., Chalmers T.C., Wang P.H.: The effect of dietary protein restriction on the progression of diabetic and nondiabetic renal diseases: a meta-analysis. Ann Intern Med 1996;124(7):627-632.

67. Pijls L.T., de Vries H., Donker A.J., van Eijk J.T.: The effect of protein restriction on albuminuria in patients with type 2 diabetes mellitus: a randomized trial. Nephrol Dial Transplant. 1999;14:1445-1453.

68. Hansen H.P., Tauber-Lassen E., Jensen B.R., Parving $H . H .:$ Effect of dietary protein restriction on prognosis in patients with diabetic nephropathy. Kidney Int 2002;62(1):220-228.

69. Suckling R.J., He F.J., MacGregor G.A.: Altered dietary salt intake for preventing and treating diabetic kidney disease. Cochrane Database Syst Rev 2012;(12):CD006763 doi:10.1002/14651858. CD006763.pub2.

70. Hall M.E., do Carmo J.M., da Silva A.A., Juncos L.A., Wang Z., Hall J.E.: Obesity, hypertension, and chronic kidney disease. Int J Nephrol Renovasc Dis 2014;7:7588 doi:10.2147/IJNRD.S39739.

71. Sahni N., Gupta K.L., Rana S.V., Prasad R., Bhalla A.K.: Intake of antioxidants and their status in chronic kidney disease patients. J Ren Nutr 2012;22(4):389-399 doi:10.1053/j.jrn.2011.09.002.

72. Szulińska M, Stępień M, Kręgielska-Narożna M, Suliburska J, Skrypnik D, Bak-Sosnowska M, Kujawska-Łuczak M, Grzymistawska M, Bogdański P.: Effects of green tea supplementation on inflammation markers, antioxidant status and blood pressure in $\mathrm{NaCl}$-induced hypertensive rat model. Food Nutr Res 2017;61(1):1295525; doi: 10.1080/16546628.2017.1295525.

73. Szulińska M, Skrypnik D, Ratajczak M, Karolkiewicz J, Madry E, Musialik K, Walkowiak J, Jakubowski H, Bogdański P.: Effects of Endurance and Endurancestrength Exercise on Renal Function in Abdominally Obese Women with Renal Hyperfiltration: A Prospective Randomized Trial. Biomed Environ Sci 2016;29(10):706-712.

74. Baggio B., Budecovic A., Vortre M.D., Soller A., Bonseghin M., Fioretto P.: Effects of cigarette smoking on glomerular structure and function in type 2 diabetes patients. J Am Soc Nephrol 2002;13(11):2730-2736.

75. Śnit M., Burak W., Kuźniewicz R., ŻukowskaSzczechowska E., Grzeszczak $\quad W$.: Leczenie nerkozastępcze chorych na przewlekłą niewydolność nerek w przebiegu nefropatii cukrzycowej dziesięcioletnia obserwacja. [Renal replacement therapy of chronic kidney disease in the course of diabetic nephropathy - 10-year observation]. Diabetol. Dosw. Klin. 2003;3(2);177-183 (in Polish).

Received: 23.05.2018

Accepted: 16.08.2018

This article is available in Open Access model and licensed under a Creative Commons Attribution-Non Commercial 3.0.Poland License (CC-BY-NC) available at: http://creativecommons.org/licenses/by-nc/3.0/pl/deed.en 